\begin{tabular}{|l|l|l||}
\hline \multicolumn{2}{|c|}{ PublisherInfo } \\
\hline \hline PublisherName & $:$ & BioMed Central \\
\hline \hline PublisherLocation & $:$ & London \\
\hline \hline PublisherImprintName & $:$ & BioMed Central \\
\hline \hline
\end{tabular}

\title{
Predicting promoters
}

\begin{tabular}{|l|l|l||}
\hline \multicolumn{2}{|c|}{ ArticleInfo } \\
\hline \hline ArticleID & $:$ & 4264 \\
\hline \hline ArticleDOI & $:$ & $10.1186 /$ gb-spotlight-20011128-01 \\
\hline \hline ArticleCitationID & $:$ & spotlight-20011128-01 \\
\hline \hline ArticleSequenceNumber & $:$ & 335 \\
\hline \hline ArticleCategory & $:$ & Research news \\
\hline \hline ArticleFirstPage & $:$ & 1 \\
\hline \hline ArticleLastPage & $:$ & 2 \\
\hline \hline & & RegistrationDate : 2001-11-28 \\
ArticleHistory & $:$ & OnlineDate $\quad$ 2001-11-28 \\
\hline \hline ArticleCopyright & $:$ & BioMed Central Ltd2001 \\
\hline \hline ArticleGrants & $:$ & \\
\hline \hline ArticleContext & $:$ & 130592211 \\
\hline \hline
\end{tabular}




\section{Jonathan B Weitzman}

Email: jonathanweitzman@hotmail.com

Finding the beginning of genes within genomic sequence presents a formidable challenge to projects to annotate the human genome sequence. In the Advanced Online Publication of Nature Genetics, Ramana Davuluri and colleagues at Cold Spring Harbor Laboratory, in New York describe a bioinformatic strategy to predict gene promoters and first exons (DOI: 10.1038/ng780). They developed a new program, called FirstEF, that attempts to predict the starts of genes. They collected over two thousand first-exons to use as a training dataset, and characterized those that were associated with a $\mathrm{CpG}$ island. FirstEF is designed to recognize $\mathrm{CpG}$ islands, promoter regions and first splice-donor sites. The program could predict $86 \%$ of all first exons with about $17 \%$ false positives $(92 \%$ of CpG-related first exons and $74 \%$ of non-CpG exons). FirstEF gave a similar performance when tested against the finished sequences for human chromosomes 21 and 22.

\section{References}

1. Computational methods for the identification of differential and coordinated gene expression.

2. Nature Genetics, [http://genetics.nature.com]

3. Cold Spring Harbor Laboratory, [http://www.cshl.org]

4. FirstEF, [http://www.cshl.org/mzhanglab] 